\title{
Estimating the economic potential of rural microregions $^{1}$
}

\author{
Norbert Grasselli \\ Regional Development Agency Észak-Alföld
}

\section{Introduction}

Experts have been involved in the problems of determining microregions in Hungary since their establishment. In Hungary, the microregions (NUTS ${ }^{17}$ IV) were established by top-down method. This system cut through existing economic and cultural connections. The villages set up their own bottom-up microregions, which have tighter connections than the official regions. In my article, I estimate the economic potential of two regions, the regions Erdőspuszta (Hungary) and Hohenlohe (Germany), after analyzing the relevant literature on determining economic potential.

Projects realized by enterprises and civil organizations have strategic significance in the economies of settlements, and it is true that their developers are not members of the formal management of the settlement. The local governments, however, should conduct realization and topdown of projects, and they have to have an image of the future and strategic plans.

The present Hungarian practice, which appears in supplyoriented applications, is not expedient over the long-run. The projects of settlements are run parallel to each other; they therefore fail to reach any synergic effect. The aim is harmonizing and building projects onto each other.

This development is assisted by Hungarian and Community sources. To utilize these sources, soundly prepared plans and strategies are necessary. The supported projects of leaders of settlements must be combined into parts of a strategic plan. Projects realized in an ad-hoc way do not serve the interests of a settlement over the long term. Leaders should be aware of the strengths and breaking points of the settlements and, on these bases, they have to work out the long-term strategic program, which should be divided into operative aims and concrete projects. While my work assists the work of the leaders of town councils in determining the breaking points, at the same time, I do not wish to identify the strategic plan to be followed. They can decide whether they want to strengthen the weak points for balanced development or build on a single potential, as the best branch.
The strategy established by the local government should be realized on a wide partnership basis by integrating civil organizations and the local economic sphere. The local government should develop its strategy on this basis. The leaders of the settlement can later conduct by an operative way by gathering the realizing projects and investments in the settlement, and by fitting its own projects into these.

\section{Raising the Subject}

Studies on microregions may be found primarily in technical literature relating to rural development. Only few experts are interested in this topic, writing excellent studies, but read by few. These publications are distinct from the publications written by extremely few experts in regional development. This phenomenon appears not only in Hungary: the overlapping is small-scaled in the literature worldwide. One of my aims of this article is to reveal, compare and analyze literature on regional development, rural development and economics regarding the topic of economic potential.

In the second part of my article, I will summarize the potential models of the literature, going through the models of regional economics, macroeconomics and especially the models used in the European Union. Information of potential model provide detailed outline than regional GDP based on estimations. The information of potential model based on investigating rural resources and worked out in my article reflects real situation. The model strives to eliminate the deficiencies of GDP, as regional GDP reflects only incomplete situation on regional processes. I investigate the literature validity of the indicators of the model in part four. The used database and methods are introduced in parts five and six. At the end, I will summarize the results of the model and draw conclusions. In the part conclusions and recommendation, I deal even with the practical utility of results and the opportunity to develop further the model.

The significance of the topic is highlighted by the continuous decrease of the role of the county within the

\footnotetext{
${ }^{1}$ NUTS: Nomenclature of Units Territorial for Statistics (Statistical territorial units): It is a territorial system for mainly statistical aims developed by the institutions of the European Union.
} 
administrative system. In developing regions, it is necessary to strengthen an intermediary level, which ensures the connections between settlements and regions. The strengthening microregions may mean this level. At the same time, it is clear that microregions have only very few information on their resources and opportunities. My article tries to help in this deficit.

My article is based primarily on studying domestic and international literature; as such an investigation has not been made before in Hungarian scientific literature. The second part of my article is supported by the secondary sources detailed in the first, broader part. I took published results into consideration and highlighted those factors which are appropriate for describing the economic potential of a microregion.

\subsection{Objectives}

The objective of my research is to assist rural local governments with their work. Through the assistance of the developed model, local governments and microregions can establish their strategic plans. The model does not determine the directions to be followed; this remains the function of the management, but the model helps in direction setting.

I based the model by processing the relevant literature. The aim of the literature processing was to gather, summarize and analyze national and international publications. One of my objectives was to compare and analyze potential definitions of different scientific fields.

My objective was to determine a new potential definition, which can be generally used. The aim of the new potential definition is to aggregate the definitions of scientific fields and to develop a definition, which can be used in every field.

The model is based on literature. During constructing the model, I try to base a coherent strategy. Data used by the model are easily available for the local governments, thus inputting data into the model is an easy task for the local governments.

The aim of the survey was to justify the results of the model. When developing the model, I took even the opinions of managers at local governments into consideration. The survey based on the opinion of the local population wishes to proof the fact that the model is well-established.

\subsubsection{Partial Potentials}

The rural economic potential is not determined in the literature, but on the other hand the definition potential is often used by publication writers dealing with the mentioned field. Mainly literature on regional development and economics define complex economic potential, but even literature on rural development and others, for example documents of the European Union use the definition potential. I introduce a few of the definitions, mainly those utilized during constricting the model. To my mind, the definitions are incomplete and imprecise, which reflect the fact that the definition of potential is not consistent both in the Hungarian and in the international literature.

In this way, my aim is to develop a new potential definition based on the listed literature. In the part of the research dealing with the partial potentials, I investigated partial potentials of tourism, labour, innovation, migration, settlement and enterprise mainly on the basis of international literature.

\subsection{Partial Potentials of Regional Economics - Problems of Approach}

Potential models of regional economics have importance in the literature on potentials. These potential models investigate the relationship of physical approach, accessibility and economic significance.

My aim is to analyze and compare these potential models and to study the fact that to what extent these models can be utilized in rural development originally developed to bigger territorial units, regions and countries. I investigate in the chapter whether the described models can be used on microregional levels.

\subsubsection{Theory of Regional Weights}

The potential model of regional economics belongs to the territorial models based on physical analogs. In the international literature, potential models evolved in Stewart's research in 1948 in connection with the quantitative revolution. There were studies on determining population (Bene and Tekse, 1966) and transportation potential (Kovács, 1976, then Papp, 1978) in the Hungarian scientific life. Haynes and Fortheringham (1991) in the English literature; and Nemes Nagy (1998) in the Hungarian literature dealt with summarizing geographical approaches. Major and Nemes Nagy utilized again potential model for determining profit potential in 1999.

Vickerman (1995) refers in the analysis, dealing with regional effects of high speed trains, that local development depends always on a certain local potential. At junctions and stops (which mean exits of motorways) the expected development, the increase of the territory in value count on the standard of local business services and local enterprises. Réthelyi and Túry see potential, attraction and competitiveness as equal concepts (Réthelyi and Túry, 2003).

\subsubsection{Accessibility and Fact of Periphery}

The periphery index belongs to potential or in other words gravity-type models. According to the supposition, the economic activity of any place depends on the distance from other economic centres and the economic size of the centre, or on the correlation of its "weight". It is an explicit similarity to the law of gravitation, that is the effect of every economic centre to any other economic centre is in direct proportion to the size of the economic activity and is in inverse relation to the distance between centres. The 
economic potential of a certain area is the totality of the interactions of the centres.

The tendency goes toward the utilization of potential models, as the dynamics of changes can be illustrated in the most suitable way by the help of potential models. The models become more and more detailed; they can be used even to 10x10 rasters. The GDP is loosing its significance in the models primarily due to the mention GDP problems.

The models of previous years use traveling time as impedance variable, as the effect of changes in infrastructure cane be reflected, which cannot be reflected as the function of the distance.

Besides accessibility models above mentioned, I investigated and evaluated the theories of regional weights, theories of accessibility and the fact of periphery, the basic accessibility indicators, travel costs, daily accessibilities, potential accessibilities, periphery indicators, gravity model indicators, traveling time/cost and daily accessibility models, the used periphery theories.

\subsection{Potential Models of Macroeconomics - Investigating the Maximal GDP}

Potential determinations of macroeconomics generally study the reaching of potential GDP and investigate the deviations of GDP by mathematical models. I introduce only the model constructed by Ghali from the potential models of macroeconomics; the results of the other models cannot be utilized during constructing my model.

Ghali (2002) in his work on Tunisian economy considers the economic potential and the total factor productivity (TFP) to be the same. TFP means the change of the barriers of economic performance in this determination.

The researcher thus follows the neo-classical economic growth model by SOLOW, which takes primarily capital accumulation and technological change into consideration. The economics uses this neo-classical model to explain the growth processes of developed countries and to investigate the sources of economic growth (Samuelson-Nordhaus, 2003).

\subsection{Summary: Potential Definitions}

The determinations of the Hungarian and international literature are widespread, but at the same time are less developed and concentrate only a certain partial field, except for potential models of regional economics, which are based on gravity theories.

Although these models were developed for bigger territorial units, they can be used for even microregional units. The models, however, consider only two main factors, the economic weight (GDP) and the physical accessibility, by which the concept potential is very simplified. To determine GDP at microregional levels is a difficult problem for the statistical systems as the value of the total products is divided from the top.

I mentioned even the potential models of macroeconomics during the survey, though these models cannot be used or may be used only in a limited way in my research as they are based on the potential national GDP determination.

\section{Information Basis}

I analyze the problems of the information basis, regional data gathering and territorial GDP and strengthen my hypoarticle revealing the unreliability of the territorial GDP.

When gathering data, besides gathering information, financial or monetary data, even basic data are gathered for example the number of flats or the number of active workers, being in the denominator of average economic indicators. In spite of the efforts of researches and statistical offices, the economic and scientific life considers the regional average gross domestic product (per capita GDP) as the main information source. The overweight of the indicator does not make following regional processes in a detailed way possible.

Besides examining the availability and evaluation of data, trade cycles of the reference period should be focused on, too, as they basically modify the indicators necessary for the regional political evaluation. The most frequently used indicators in the political life are demographic, productivity, profit and employment indicators. Politics tries to explain the regional and social differences to regional population by utilizing the indicators above mentioned. Such a difference is the difference between cities and villages. The professional debate on facts and placing the data in proper time and space is relevant as this may provide explanations to empirical observation as well as solving strategies for the future. Using simply and transparent indicators and dividing data into regions and periods make the evaluation of data possible. The quantity and availability of data have been improved thank primarily to the work of statistical offices and the legal regulation. The statistical offices, however, carry out only expost evaluation.

I mention the details of data problems of regional and rural economics only in a few thoughts.

- Places of work and residence: places of work and residence of employers in rural areas and around city agglomeration situate in different settlements, or possibly in different regions. Before data gathering, it must be made clear, that whether the population of the place of residence or of the place of work, as well as the profit realized in the place of residence or in the place of work is considered during data gathering.

- Gross and net values: the difference between gross and net values is the value depreciation or amortization. Before data gathering one has to fix the method of handling depreciation that is whether the gross or net values are evaluated.

- Market value or accounting price: subsidies generally serve establishing fixed assets. Before data gathering, it must be defined whether the established assets are registered in market value or in accounting price.

- Partial or complex performance indicators: when determining performance indicators, such as produc- 
tivity or efficiency indicators, it is necessary to cope with the problems of numerator and denominator.

\subsection{Summary: Regional Indicators}

The regional indicators by which literature tries to define the development of an area or a region are loaded with deficiency and inaccuracy. Such indicators being most often used are the GDP and unemployment.

The indicator unemployment involves only the registered unemployed, thus it does not reflect the real number of the unemployed. The appropriate indicator for measuring unemployment is to determine the number of inactive population on the basis of the introduced method.

When dealing with the problems of GDP, I focused on the problems of determining the territorial GDP. The territorial GDP is significantly distorted by the effects of commuting, the division of multi-regional organizations, and the upbottom-method of the Hungarian Central Statistical Office (KSH).

It is a problem that GDP is based on profit data according to the place of work and not according to the place of residence, which means a distorted effect in case of rural microregions. Employers often commute from the settlements of the rural microregions to the microregional centers, but their profit is not reflected in the territorial GDP. Due to the problems above mentioned, the values of the territorial GDP cannot be accepted without stipulations.

\section{Basing the Model}

I cope with the theoretical and literature basis of the model in the fifth part of my article. I overviewed the territorial indicators in the international and national literature. The chapter follows the structure of the model, and consists of parts on the basis of partial potentials. The indicators found in the literature are examined, summarized and evaluated with respect to the certain partial potentials.

I investigated territorial, demographic, profit, human index, accessibility, migration, labour, infrastructural, tourism and enterprise indicators in the chapter.

The complex economic development indicators are the most comparable to the described economic potential indicator. It must be mentioned, however, that these indicators concentrate only on economic development of the past, do not give answers to future opportunities. Researchers often do not explain or hardly explain involving indicators into the model. The indicator groups used in the models are similar, at the same time the indicators of the indicator groups differ significantly from each other. Among the indicator groups, I took several indicators into the model.

Based on literature I have developed the definition of the rural economic potential. According to the definition the rural economic potential is the sum of local resources, which can be the basis of a new strategic program.

\section{Database}

I introduce the database used during my research in the sixth part of my article. The database do not serve enough information source in every case, thus I supplemented the data with own data gathering. I carried out data gathering in 2002 and 2003 in Germany and in Hungary. The Tempus scholarship financed by the European Union helped in the German data gathering. I based the indicators described in the fifth part in the previous chapters in my article. When selecting the indicators, I considered the literature background and the opportunity of the realization.

During my investigation I used the following database and data:

- Statistical yearbook of the Hungarian Central Statistical Office, 2002 (KSH)

- on-line database of TEIR

- Database of General Agricultural Survey (ÁMÖ), 2000

- Own data collection in the microregion of Erdőspuszta

- on-line database of Statistisches Amt BadenWürttemberg

- Own data collection in the region of Hohenlohe.

When making indicators I took the availability of data into account. When determining the necessary data, I considered the fact, which data are easily available for decision-makers of settlements. During constructing the model, I tried to make the model to be utilized in general and even at international level. The next table shows the developed partial potentials and indicators.

\section{Data Used in Analyzing}

In the sixth part of my article, I deal with the collected data both in Germany and in Hungary and the difference between them on the basis of the indicators introduced above. First, I carried out the introduction and analyzing of the microregion Erdosspuszta, then I introduced the microregion Hohenlohe and analyzed the value of indicators of the indicator groups.

\subsection{Erdöspuszta}

The Association of the Self-Governments of Erdőspuszta (Erdöspuszta) is one of the most active microregions in the Eastern part of Hungary. It consists of ten settlements such as Álmosd, Bagamér, Hajdúbagos, Hosszúpályi, Kokad, Létavértes, Mikepércs, Monostorpályi, Sáránd and Újléta.

The aim of the joined settlements is to reach higher living standard for their population helping each other and cooperating with each other. The history of the settlements shows similar facts, though the settlements differ from each other from many aspects. This is reflected even in the collected data. 
Table 7.1.: Partial Potentials and Indicators

\begin{tabular}{|c|c|c|}
\hline Partial Potential & Primarily Indicators & Secondary Indicators \\
\hline \multirow[t]{3}{*}{ Accessibility } & Cars & Traveling time \\
\hline & Public transportation & $\begin{array}{l}\text { Frequencies of bus lines to the nearest economic } \\
\text { junction }\end{array}$ \\
\hline & & $\begin{array}{l}\text { Frequencies of railway lines to the nearest economic } \\
\text { junction }\end{array}$ \\
\hline \multirow[t]{4}{*}{ Demography } & Human index & Number of classes \\
\hline & Labour & Number of the registered unemployed \\
\hline & & Education of the unemployed \\
\hline & & Age of the unemployed \\
\hline \multirow[t]{7}{*}{ Enterprises } & Operating joint ventures & Number \\
\hline & Available industrial site & Size \\
\hline & Agricultural land & Size \\
\hline & Taxation & Industrial tax \\
\hline & Tourism & Number of beds \\
\hline & & Number of tourism nights \\
\hline & & Number of catering places \\
\hline \multirow[t]{5}{*}{ Built environment } & Public utility & Ratio of cleaned sewage \\
\hline & & Water pipe system \\
\hline & Culture & Number of sights \\
\hline & Forest & Ratio of the whole territory \\
\hline & Infrastructure & Ratio of paved roads from the whole roads \\
\hline \multirow[t]{5}{*}{ Natural resources } & Raw materials & Number \\
\hline & Land quality & Golden-crown \\
\hline & Nature conservation & Size of the territory \\
\hline & & Number of protected habitats \\
\hline & & Size of protected water basis \\
\hline \multirow[t]{8}{*}{ Community sources } & Public health care & $\begin{array}{l}\text { Opening hours of surgery projected to } \\
1000 \text { inhabitants }\end{array}$ \\
\hline & & $\begin{array}{l}\text { Number of general practitioners projected to } \\
1000 \text { inhabitants }\end{array}$ \\
\hline & & Utilization of capacities in old people home \\
\hline & Services & Number of non-profit organizations \\
\hline & & Number of personal services \\
\hline & Management & Number of applications \\
\hline & Education & Number of institutions \\
\hline & Poverty & Ratio of social fund receivers \\
\hline
\end{tabular}

article, where the size of the indicator of every settlement is illustrated in each axis. The aggregated indicators of the results reflect the rate of partial potential of the settlement in the major six axes. The graphical introduction of the model is reflected by the example of 2-2 settlements.

\subsection{Microregion Erdöspuszta}

Mikepércs belongs to settlements having imbalanced potential. The most favorable partial potential of the settlement is the partial potential accessibility, which received 239 scores. All the other partial potentials do not exceed 120 scores.

Mikepércs has outstanding opportunities in case of accessibility (Figure 8.2.). The management of the settlement may determine to improve the other partial potentials. Especially, partial potentials demography and built environment show low numbers. Thus, management should focus on improving these two indicators in the field of a given strategy.

The partial potential of the settlement may be reflect by a single aggregated number; in this case the potential has 114.16 scores. This aggregated potential, however, do not show the differences mentioned above, that is the extreme high value of the partial potential accessibility and the low value of partial potential enterprises and built environment.

\subsection{Hohenlohe}

The microregion Hohenlohe is a self-organized microregion in Germany, in the Northern part of BadenWürttenberg, by near the city Heilborn. The microregion consists of 7 settlements, such as Dörzbach, Ingelfingen, Jagsthausen, Krautheim, Mulfingen, Schöntal and Widdern.

The reason for establishing this microregion was to realize a common rural development program. Recognizing their common interests, these settlements have been cooperating with each other since 2000, on the basis of common past and geographical accessibility.

\section{Results of the Model}

I illustrate the calculated indicators on the basis of the method outlined in the previous chapter and in the appendix 1. I show the results of the model in the eighth part of my

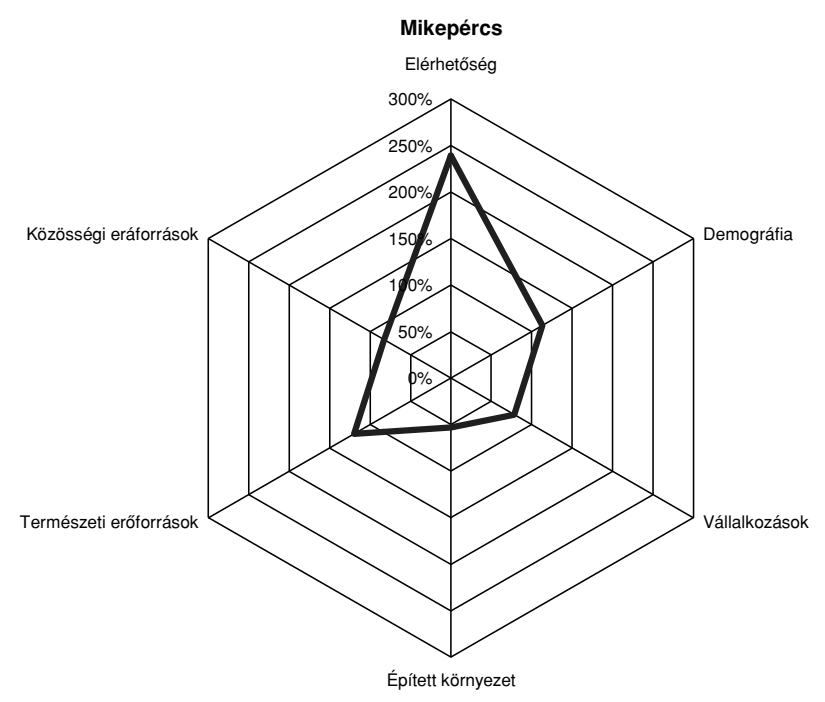

Figure 8.2.: Graphic Model of the Potential of Mikepércs 
Létavértes shows a potential equilibrium, four of the six potentials are between 100 and 150 points. The partial potential community resources have 13 scores. The partial potential demography reached 71 scores.

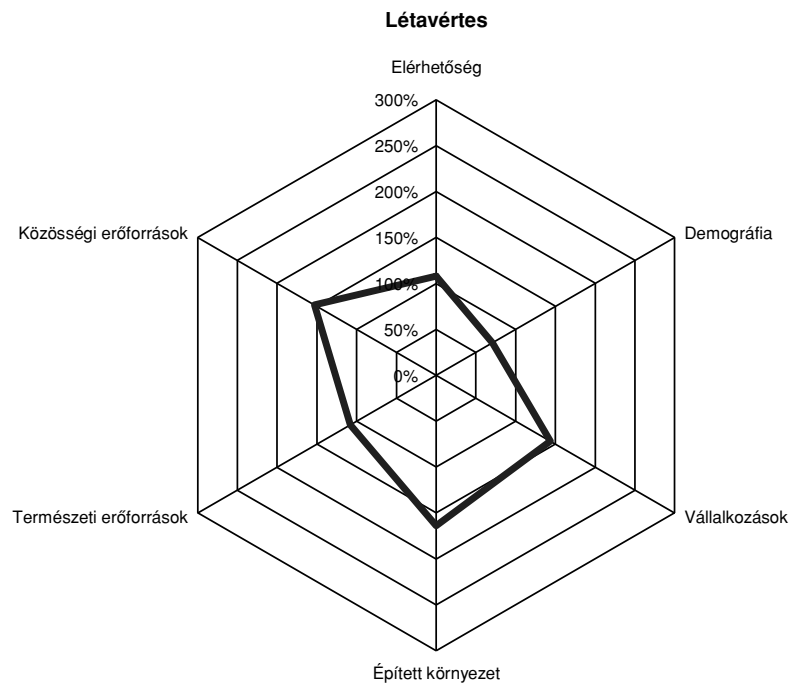

Figure 8.3.: Graphic Model of the Potential of Létavértes

The leaders of the settlement must build up a strategy to increase the demographic potential if they want to achieve a full equilibrium. Naturally, increasing indicators are important for leaders and not decreasing indicators to the same level, similar to the policy of the European Union striving for regional equilibrium.

The aggregate potential is 126,16 , which is only 12 points higher than the potential of Mikepércs, although the potentials show very different possibilities (Figure 8.3.). Investigating the partial potentials, however, the settlement can set a much more balanced growing cycle as an objective. The settlement strategy probably concentrates on the improvement of partial potential of demography.

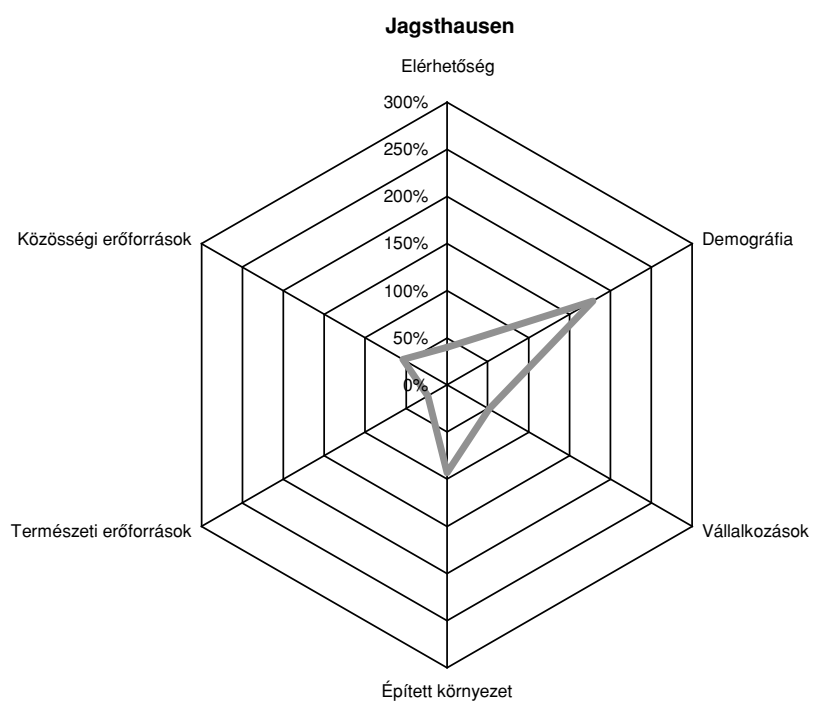

Figure 8.5.: Potential Indicators of Jagsthausen Settlement

\subsection{Microregion Hohenlohe}

This situation may be discovered in Jagsthausen (Figure 8.5.). The highest partial potential of the settlement is the demographic partial potential with a number of 178 . Partial potential built environment also reaches very high value.

The aggregate potential show 73,16 . At the same time this indicator does not reflect the potential opportunities of the settlement. The potential can only be understood in regional context. It can not be separated from the microregion or the researched area. Differences of partial potentials confirm the opportunity net of settlements.

The settlement has only one outstanding partial potential. In order to change this situation, leaders should strengthen the other partial potentials. The difference of 155 scores between demography and natural resources may be considered as an extremely significant problem.

Schöntal has a potential equilibrium, compared to other settlements in Hohenlohe. Schöntal has balanced opportunities in this economic and territorial environment. The lowest partial potentials are the nature and the accessibility potentials.

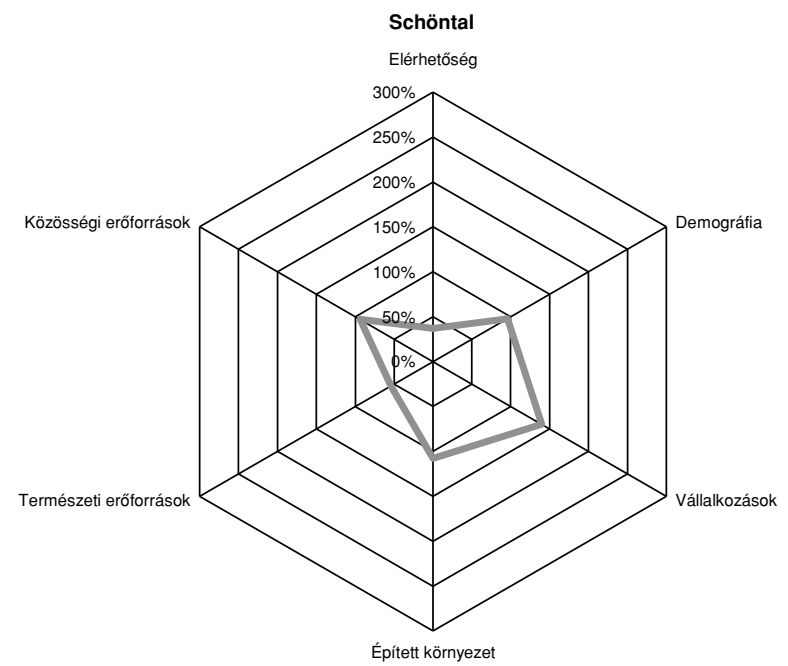

8.6. ábra: Potential Indicators of Schöntal Settlement

The aggregate economic potential is 88,16 . That means only 15 points difference between Jagsthausen (Figure 8.6.) and Schöntal. At the same time Schöntal shows a more balanced condition in comparison with Jagsthausen. In the figure, the distance from the centre in case of four potentials show numbers between 90 and 150 in the axis.

The potential as an aggregate indicator may be calculated in a given regional context. On the other hand, it must be determined that the potential in a single number do not describe the rate of the economic potential. The indicators of partial potentials and their deviations provide information for the leaders of the settlements. By utilizing this, the management can plan the strategic tendency for the future both in the settlement and in the microregion. Striving for equilibrium may mean a way to be followed. 


\section{Analyzing Results of the Model}

Graphic illustration of results of the model provides figures easy to understand. The highest and lowest values are easily recorded. Determining the values behind the indicators needs a more detailed analysis.

\subsection{Result of Model Calculation}

Figures above illustrated reflect the developmental level of settlements. Naturally, the potential may be expressed with a single number. Though it is a complex indicator, it does not provide extra information. The complex index aggregates several typical indicators, where every indicator contributes to the whole and the lack of certain indicators may worsen the effect generated by other typical factors.

The strength of certain partial potentials is illustrated by the position in the axis. The higher the number of certain axis it is, the stronger the given partial potential in the settlement it is. The partial potentials of settlements may be aggregated, which result in the partial potential of a microregion as well as the potential value of a microregion. This indicator group has more significant content than the generally used indicator GDP.

\subsection{Results of Analyzing Questionnaires}

I checked the results of the model by carrying out two surveys. I executed the survey in the 2002. This is the year from which the data originate. I had the opportunity to fulfill the survey in Germany by the help of the Socrates/Erasmus scholarship and the University of Hohenheim. When doing the Hungarian survey, I used the data of the Regional Association of Self-Governments of the Debrecen Agglomeration.

I used simple statistical methods when analyzing the questionnaires. I calculated modus, median, and correlation coefficient. The survey is not relevant because of the low number of elements in the pattern. The ratio of respondents from the whole population is 5\% in Erdöspuszta, it is $2 \%$ in Hohenlohe. We had altogether 360 questionnaires filled out in Erdőspuszta, 50 questionnaires in larger settlements (Hosszúpályi, Mikepércs and Létavértes), and 30 questionnaires in smaller settlements. The number of respondents was 150 persons in Hohenlhole, where 30 persons answered in larger settlements (Schöntal, Mulfingen, Ingelfingen) and 15 persons in smaller ones. The aim of the survey was to check the result of the model. The questionnaire consisted of seven main parts.

The structure of the questionnaire:

1. The economy of the settlement

2. Aims of the settlement

3. Tasks of the settlement

4. Rural life

5. EU accession

6. Personal data

7. Data of place of work
Before comparing the results of the survey done in the two microregions to the results of the model, I begin with answers of residents from several selected settlements. $66 \%$ of the respondents consider Monostorpályi as agricultural settlement, $22 \%$ of them as settlement for residence in the attraction of a big city, while 6 respondents characterized the settlement as of mixed functions.

What Regional Economic Functions Does the Settlement Have?

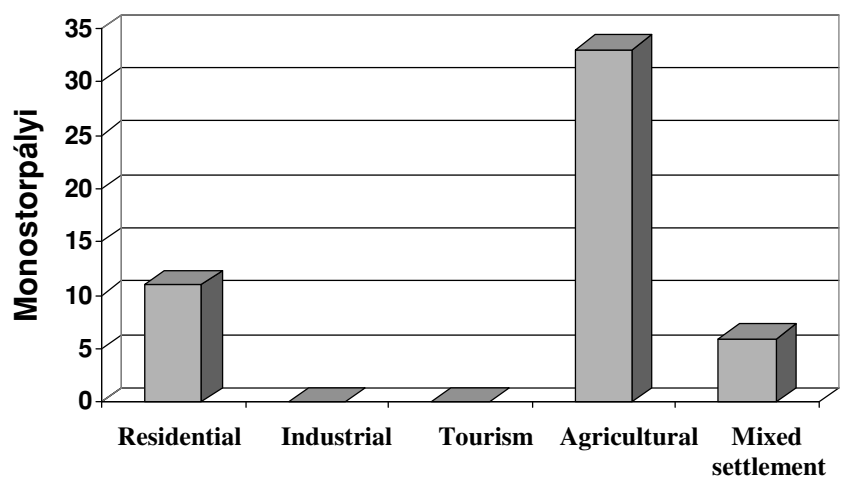

Figure 9.1.: Economic Functions of Monostorpályi on the Basis of Answers of the Questionnaires

The question serves revealing the situation of the settlement. The aims and tasks of the settlement helped in the control whether the problems determined in the model were real. Besides local government, the agricultural enterprise formed from the co-operative is considered to be the biggest employer in the settlement.

In Monostorpályi the strongest partial potentials are demography and natural resources having 164 and 144 scores, respectively. Within the partial potential demography, the ratio of the registered unemployed is low, while the indicator education of the unemployed reflects high value. Within the partial potential natural resources, the indicators raw materials and protected habitats reached high value.

During giving answers, the inhabitants highlighted the advantages of healthy environment and the high number of employed (especially in the field of agriculture). In Monostorpályi the partial potentials community resources and built environment reflect low values (47 and 92 scores). The low rate of community resources is caused by the lack of

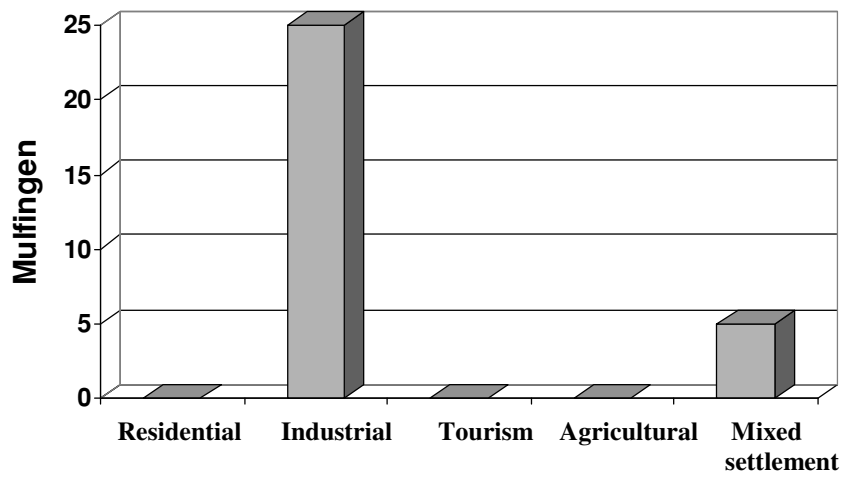

Figures 9.5.: Economic Functions of Mulfingen on the Basis of Answers of the Questionnaires 
surgery room and the low number of applications. Surprisingly, those who answered to the questions highlighted only the deficiencies of built environment and the need for development, such as building further paved roads and the improvement of canalization. There is not any cleaned sewage in the settlement and the ratio of paved roads is also small (29\%).

I asked 30 persons during the survey in the German settlements. I selected a 30-person-pattern even in the settlement Mulfingen.

More than $83 \%$ of the respondents characterized the settlement as industrial settlement; others described it with mixed functions. This is based by the fact that more than $70 \%$ of the employees wok for the EBM factory and the JAKO commercial company.

The partial potentials demography and built environment are the highest in Mulfingen. Every respondent mentioned the developed industry of the settlement, especially the EBM factory then the JAKO commercial company, whose activities resulted in low unemployment rate. The answers emphasized the built environment among the problematic fields as the abandoned farm buildings in the city center spoil the city image. The model does not cover this field. The lowest partial potential in the settlement is accessibility.

\subsection{Summary}

When comparing the two examined microregions, I concluded that although the partial potentials of the microregion Hohenlohe is smaller, the potential is in equilibrium to a larger degree than in the settlements of Erdöspuszta. "Standing on more feet" is more frequent in the German settlements that is the number of stronger potential is higher. In Hungarian settlements, a single outstanding potential is typical.

Determining potential can be considered to be a tool, which helps in preparing decision making, which may help in strategic planning of settlements. The management of the settlements can decide whether they will build their strategy on one potential of outstanding or they wish to improve the other, lagged behind potentials. In case of selecting the second solution, the indicators to be improved may be found in the model.

The results of survey did not prove completely the result of the model. According to the inhabitants, the most critical fields do not cover entirely those indicated by the model. One of the reasons of the difference is that the inhabitants do not always know the strengths and problems of the settlement. It turned out in several cases that even the leaders of the settlement are not aware of the significant indicators including the number of services, ratio of forest or the number of tourism nights.

I had to conclude that there are fields that cannot be covered by the model, for example, the problems of abandoned farm buildings in the center of Mulfingen. The model is not deal with the investigation of these buildings and the effects. The model is not capable of reflecting the reality completely; on the other hand it may provide relevant assistance for decision makers.

Reflecting the economic potential with a single number provide only little information and make the comparison of settlement at only regional level possible. Determining the partial potentials may provide supplementing information, the differences of indicators mean this additional information. On this basis, the management can determine the major tendency of the strategy by either equalizing the opportunities of the settlement or concentrating the one or two significant sectors. Thus the strategy may be equalizing, closing up and concentrating strategy.

In the case of equalizing and closing up strategies, the settlement focuses on equalizing the partial potentials, the opportunities. Investments are carried out, which strengthen the weak partial potentials. Obviously, this determination supposes the principle mentioned during describing the model, that settlements and microregions follow conscious strategy and do not follow the obligatory tendency paved by the state and community applications.

When choosing the concentrating strategy, the settlement focuses on outstanding partial potential or potentials. The settlement handles the outstanding partial potentials as peak sectors and it builds the other sectors on the basis of the generated effects.

The graphic model makes the quick illustration of the rural economic potential possible. The figures mean a strategic tool developed easier for the management and the mayor.

\section{Conclusion and Recommendations}

In the ninth part I introduce my developed new and novel scientific findings, I emphasize the practical utility of the results and I propose recommendations for developing further the model. In the part of the practical utility of the results, I established my recommendations by consulting the mayors of settlements in Erdöspuszta. I considered the actual technical literature and the concerned in regional development when realizing my theories.

On the basis of studying the technical literature I concluded that studies in rural development, regional economics and economics cope with the issue of economic potential from different approaches. When comparing the different theories, I wound up that regional development deal with economic potential from an accessibility aspect, while according to the economics, the central issue of economic potential is to maximize the GDP, rural development tried to determine the complex economic potential, though the state investigated partial results defined as partial potential. In order to harmonize the differences observed during analyzing the technical literature, I recommend starting interdisciplinary consultations between scientific fields in the issue of economic potential.

When investigating the database I determined the problems of the generally used indicator GDP. The critics of GDP were mentioned even from a macro-economic aspect, 
but I focused on studying regional GDP in my article. I concluded that the calculation of the regional GDP is often based on estimations and extrapolations thus this indicator may be considered to be extremely unreliable. I recommend data collection by the method of bottom-up when calculating the GDP, which would result in more reliable data and it even harmonizes with the principle of the European Union relating to subsidiary.

I created the indicator of rural economic potential, which was utilized for investigating Hungarian and German settlements. I made several conclusions during the research, introducing settlements as examples. I recommend using the indicator of rural economic potential for the management of settlements, as the gained information introduces results by figures easy to understand. On the basis of this indicator, the management of the settlement may determine the tendencies in strategy striving to equilibrium or concentration.

During the survey, I tried to prove the results of the indicator and concluded that the operation of the indicator is satisfactory, though it is not able to cover all aspects of the economy of the settlement. Furthermore, I concluded that the awareness of the population on the settlement is little, thus I recommend developing communications with inhabitants for the management, especially regarding the economic situation of the settlement.

\section{References}

1260/1999 EC: Council Regulation (EC) No 1260/1999 of 21 June 1999 laying down general provisions on the Structural Funds, Brussels

ERDF (2000): The territorial effects of the structural and cohesion funds, ESPON, Brussels

ERFA (1999): Europäische Komission Generaldirektion für Regionalpolitik und Kohäsion, Der neue Programmzeitraum 20002006: methodische Arbeitspapiere, Indikatoren für die Begleitung un Bewertung, Arbeitspapier 3, Brussels

HM TREASURY (2000): Realising Europe's potential, Economic reform in Europe, Chancellor of the Exchequer, London
UN Human development report (2004): http://hdr.undp.org/

OECD Organisation for Economic Co-operation and Development (2002): Measuring the Information Economy, OECD, Paris, www.oecd.org

United Nations Conference on Trade and Development, UNCTAD (2002): Unctad Benchmarks Fdi Performance, Potential, ThisDayOnLine, 2003. 08. 06.

Stewart, J. Q. (1948): Demographic Gravitation: Evidence and Application. Sociometry 1

Bene L. - Tekse K. (1966): Vizsgálatok a népesség területi eloszlásának alakulásáról Magyarországon 1900-1960. KSH Népességtudományi Kutatóintézet Közleményei 9., Budapest

Kovács CS. (1976): Főbb településeink egymáshoz viszonyított vasúti átlagtávolságai és forgalmi potenciáljai, in. Enyedi Gy.: A magyar népgazdaság fejlődésének területi problémái, Akadémiai Kiadó, Budapest

Papp A. (1978): A Tiszántúl középső részének központjai, területi elrendeződésük, potenciáljuk, Földrajzi Közlemények 26/CII/3

Haynes K. E. - Fortheringham A. S. (1991): The Impact of Space on the application of Discrete Choice Models, Review of Regional Studies, 20 (2)

Nemes Nagy J. (1998): A tér a társadalomkutatásban, Bevezetés a regionális tudományba - Gravitáció és potenciálmodellek, EmberTelepülés-Régió 2., MTA Stratégiai Kutatások, Budapest

Major K. - Nemes Nagy J. (1999): Területi jövedelemegyenlőtlenségek a kilencvenes években, Statisztikai Szemle 77

Vickerman R. W. (1995): Regional impacts of trans-European networks, The Annals of Regional Science 29: 237-254

Réthelyi ZS. - Túry G. (2003): A közlekedési hálózatok és a térségi (regionális, országos) fejlettség összefüggéseire vonatkozó hazai és nemzetközi szakirodalom áttekintése, és ennek alapján a hálózati hatékonyság és versenyképesség megfogalmazása, értelmezése, A Gazdasági és Közlekedési Minisztérium: „VIII. A hazai közlekedési hálózatok hatékonysága, versenyképessége növelésének lehetőségei a nemzetközi tapasztalatok alapján" címü kutatási témához készült tanulmány, Budapest

Ghali S. (2002): TFP and Economic potential of the Tunesian economy, Département des Sciences Economiques, Faculté des Sciences Economiques et de Gestion de Tunis, Université de Tunis, El Manar

Samuelson D. - Nordhaus G. (2003): Közgazdaságtan, KJK, Budapest 
